\title{
Habitat and nest placement of Red-backed Shrikes Lanius collurio breeding in clear-cuts in southern Norway
}

\author{
Terje Lislevand
}

University Museum of Bergen, Natural History Collections, University of Bergen, P.O. Box 7800, 5020 Bergen, Norway. E-mail: terje.lislevand@um.uib.no

\begin{abstract}
Information on habitat, nest placement, phenology and clutch size in Red-backed Shrikes Lanius collurio was collected from a total of 71 nests in southern Norway during 1995-2009. In this area, which is situated at the north-western limit of the species' distribution, breeding was predictable in clear-cuts in pine Pinus sylvestris forest where junipers Juniperus communis made up a large part of the shrub layer. This contrasts with previous descriptions of typical shrike habitat in clear-cuts which focused on the availability of young spruce Picea abies trees. Nests were almost exclusively located in Junipers (92\%), further emphasizing the importance of this bush species as part of the shrike habitat in the study area. Mean nest height was $113 \mathrm{~cm}$ (range $0-250 \mathrm{~cm})$ and increased with height of the nesting bush (mean $=225$, range $120-400 \mathrm{~cm}$ ). However, this increase was lower than expected if the relationship was simply proportional, indicating that the birds prefer to place their nests low in the vegetation even if higher alternatives are available. Clutch size ranged from 1 to 7 eggs (mean $=5.1)$ and estimated dates of first eggs varied from 10 May to 16 June (median $=3$ June). Breeding time varied significantly between years but there was no correlation between breeding time and clutch size. Both height of nest and height of the nest bush increased significantly with breeding season, and possible reasons for these findings are discussed.
\end{abstract}

Key words: breeding; forest management; juniper; nest height; shrikes

\section{INTRODUCTION}

In the Nordic countries, many bird species traditionally regarded as typical farmland birds now also commonly occur in forest clear-cuts (Ottvall et al. 2007). In some of these there has been a considerable population decline over recent decades. An example is the Red-backed Shrike Lanius collurio which is an early successional bird which requires sun-exposed and open hunting areas with dense shrub for nesting (e.g. Durango 1956, Olsson 1995a). The species is common in a range of European cultivated landscapes and its decline has been largely attributed to changes in agricultural practice which generally caused overgrowth of formerly open farmland (Roos 2005). On the other hand, since the 1950s clear-cut forestry, or more recent partial clearcut harvesting techniques ("retention cuts"; Söderström 2009), continues to create new breeding habitat for the species in many areas, probably compensating for the loss of habitat in farmland (Solheim 1992, 1994). Recent studies comparing breeding performance in agricultural landscapes and clear-cut areas (Karlsson 2004, Söderström \& Karlsson 2011, Hollander et al. 2011) largely agreed that shrikes preferred clear-cuts over farmland, but concluded differently as to whether this preference resulted in improved breeding performance.
It is well known that nest site selection may be critical for breeding success in birds by influencing the risk of predation (Martin 1993) or by affecting the microclimatic conditions in and around the nest (e.g. Hatchwell et al. 1996, D'Alba et al. 2011). For birds which place their nests in shrub or other plant cover, choosing the optimal plant species for nest concealment may be crucial. For instance, dense and thorny bushes may both conceal the nest and provide some protection against predators (Tryjanowski et al. 2000). It may also be adaptive for birds to place their nests at a certain height above ground. Thus, in some shrike species and other passerines nest height increases over the breeding season (Rich 1980, Gawlik \& Bildstein 1990, Woods \& Cade 1996, Takagi \& Abe 1996), possibly as a means of reducing predation risk or improving ventilation in warmer environments.

Red-backed Shrikes place their nests about 1-1.5 m above the ground in a variety of plant species, the most typical being thickets and dense, thorny shrub such as hawthorn Crataegus spp., blackthorn Prunus spinosa, bramble Rubus spp. and roses Rosa spp. (Cramp \& Perrins 1993, Olsson 95b, Lefranc \& Worfolk 1997, del Hoyo et al. 2008). In some areas junipers Juniperus communis are also important nest sites (e.g. Olsson 1995b). At least in the Nordic countries young spruce 


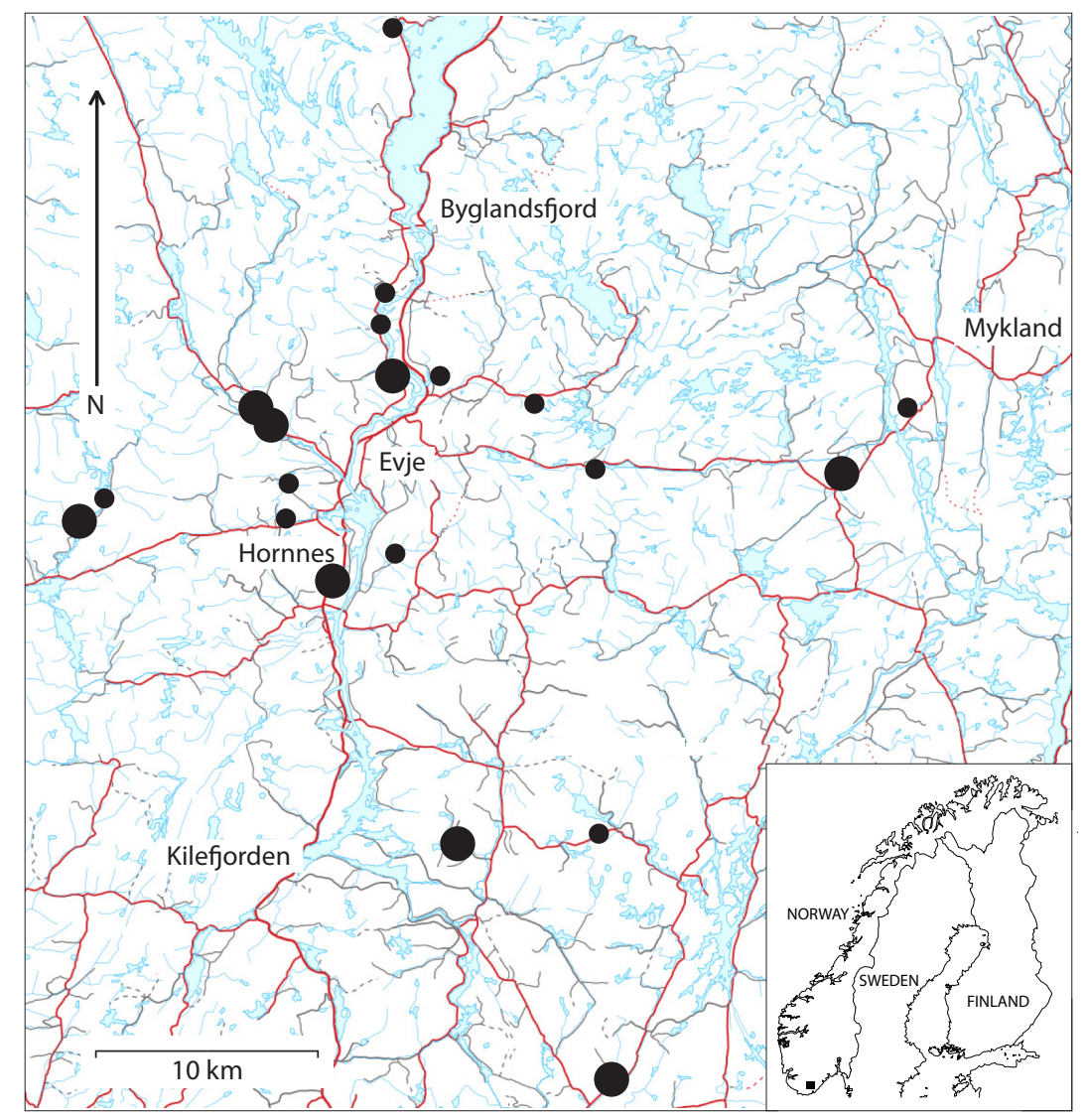

Figure 1. Map of the study area and nest areas in Aust-Agder county, southern Norway. The location is indicated by the black square on the inserted map of Fennoscandia in the lower right corner. Small black dots indicate breeding sites where single nests were found, whereas large dots show areas with 2-5 nests per season. Blue areas: streams and lakes; red lines: main roads. Note that not all areas were searched in each year and that the map does not show all sites housing shrikes within the mapped area.

Picea abies plantations are reported to constitute an important part of the breeding habitat and spruce is a typical plant species for nest location in clear-cuts (Solheim 1992, 1994, Lefranc \& Worfolk 1997, Roos 2005, Söderström \& Karlsson 2011). However, there is little information about habitat and nest placement on clear-cuts where spruce is less common.

In Norway the Red-backed Shrike is classified as Near-threatened in the national Redlist (Kålås et al. 2010). Yet, previous reports on both the population status and breeding biology of the species in Norway have been largely anecdotal. Consequently, for conservation purposes, and for improving our general knowledge about the species' biology, more information on habitats, nest sites and general ecology is required. I studied Red-backed Shrikes in AustAgder, southern Norway; i.e. near the north-western limit of the species' distribution area. Here the species is a locally common breeder in some clear-cuts in pine Pinus sylvestris forest. The purpose of this paper is to provide a general description of the species' breeding habitat and to present data on nest site selection in this part of Norway. In addition, I report on nesting phenology and clutch size. I checked how nest height was associated with height of the nest bush. If nests are placed at a certain preferred height, as suggested from many previous studies (see above), I expected nests to be located relatively low even in tall shrub. Finally, I analyzed whether nest height increased over the season, as one might expect from some observations in other passerines.

\section{METHODS}

\section{Study area and data}

I collected data on nest sites and breeding biology of Red-backed Shrikes in the south-western parts of AustAgder county, southern Norway (Figure 1), during nine summers in the period 1995-2009. Nest areas were located between c. 180 and $330 \mathrm{~m}$ asl. Throughout this region the landscape is dominated by coniferous forest, primarily consisting of pine, although spruce also occurs in many places. Forestry is widespread and clearcuts or retention cuts of varying successional stages are 
common (the latter more common than the former). For simplicity I here refer to such areas as clear-cuts, since in most cases I have no information on the degree of clear-cutting. Data exist from a total of 71 nests or broods ( 2 in 1995, 19 in 1996, 12 in 1997, 5 in 1998, 1 in 2000 and in 2001, 6 in 2004, 16 in 2007 and 9 in 2009), most of which were found in the municipalities Evje og Hornnes $(\mathrm{n}=50)$, Iveland $(\mathrm{n}=11)$, and Birkenes $(\mathrm{n}=$ 8) (Figure 1). The majority of these were checked by the author but information from 21 nests was provided by two independent observers. In several areas I found the shrikes breeding on apparently contiguous territories with up to at least five nests and/or broods located in the same clear-cuts. Not all areas were checked each year, nests of many territorial birds were not found and many nest areas have certainly gone undetected. Hence, this study does not give a representative picture of the total population size within the study area.

\section{Field procedures}

Nests were located by watching for parents feeding chicks or males feeding incubating females. Recorded variables on nest placement included species of bush where the nest was located, height off the ground and total height of the nest bush/tree. The two latter variables were estimated by sight. Field work was normally conducted in a restricted part of the breeding season around the time when chicks could be ringed, in most cases from mid June to the first days of July (median nest finding date across years $=25$ June, quartiles $=21$ June and 3 July, range 30 May-13 July). Hence, egg-laying dates were never directly recorded and in many cases hatching dates and clutch size are not known with absolute certainty. When not directly observed I estimated hatching date by back-dating the number of days equal to the age of chicks (Olsson 1995b, Söderström \& Karlsson 2011) as judged in the field or from photos. When this was not possible I roughly estimated chick age from field descriptions as 1 day (newly hatched), seven days (half grown chicks and chicks ringed with no further information on age), 12 days (large chicks), 15 days (brood "exploded" at nest approach) and 17 days (chicks unable to fly but had left the nest). Egg-laying date of the first egg was estimated by back-dating from the estimated hatching date, assuming an incubation period of 14 days and adding one day per egg to account for laying (Olsson 1995b). Since estimates of laying dates depended on information about clutch size, sample size was higher with regard to hatching dates. Hence, when checking for effects of seasonal progress I only present results from tests using hatching date as an estimate of breeding phenology. However, using laying dates instead did not change the conclusions in these cases (results not shown). Clutch size was recorded from the number of eggs or chicks observed in the nest. In most cases I visited nests with eggs at least twice but on different days to confirm that clutches were completed. However, I was not able to rule out the possibility that some nests might have been partially depredated or that parents removed failed eggs from the nest before I found them. This risk is illustrated by two nests where a single egg or chick was evidently lost within seven days after hatching. Consequently, some of the clutch sizes in this study might have been underestimated. Because I often checked the same areas for nests in several years there is a chance that some individuals or pairs might have been included more than once in the analyses.

\section{Data analyses}

I used IBM SPSS Statistics 19 for all analyses. All variables could not be recorded in each nest. Hence, sample sizes vary among variables. To analyze how nest height was related to bush height I used a linear regression with nest height as dependent variable. I estimated the slope (beta) of the regression line to see if nest height increased proportionally with shrub height, in which case the slope would not differ from one. I tested if this was the case by checking whether the $95 \%$ confidence interval (CI) for beta included the value 1 . I report results on both absolute and relative hatching dates. In the latter case each hatching date was controlled for between-year differences by subtracting the median hatching date for the year in question. Hence, relative hatching dates are given as prior to (negative values), after (positive values) or equal to the median date (zero). Means are given \pm SD throughout.

\section{RESULTS}

Red-backed Shrike territories were typically found in open forest areas dominated by pine trees but where a large proportion of the trees had been logged. In addition, about one-three meter tall junipers normally made up an important landscape characteristic by dominating the shrub layer (Figure 2a, b). As the time since clear-cutting varied from place to place and from year to year, nest areas varied in the degree of plant succession and tree height. In one extreme a nest was found in a clear-cut area with almost no shrub layer at all, while in other sites the forest grew so dense over the years that the shrikes eventually disappeared as breeding birds. As a general rule, though, Red-backed Shrikes were normally absent from clear-cuts with little juniper shrub. The occurrence of Junipers did not appear to be an effect of succession following clearcutting but rather that this shrub was common in the areas before logging took place. Consequently, many clear-cuts where junipers were not common probably 

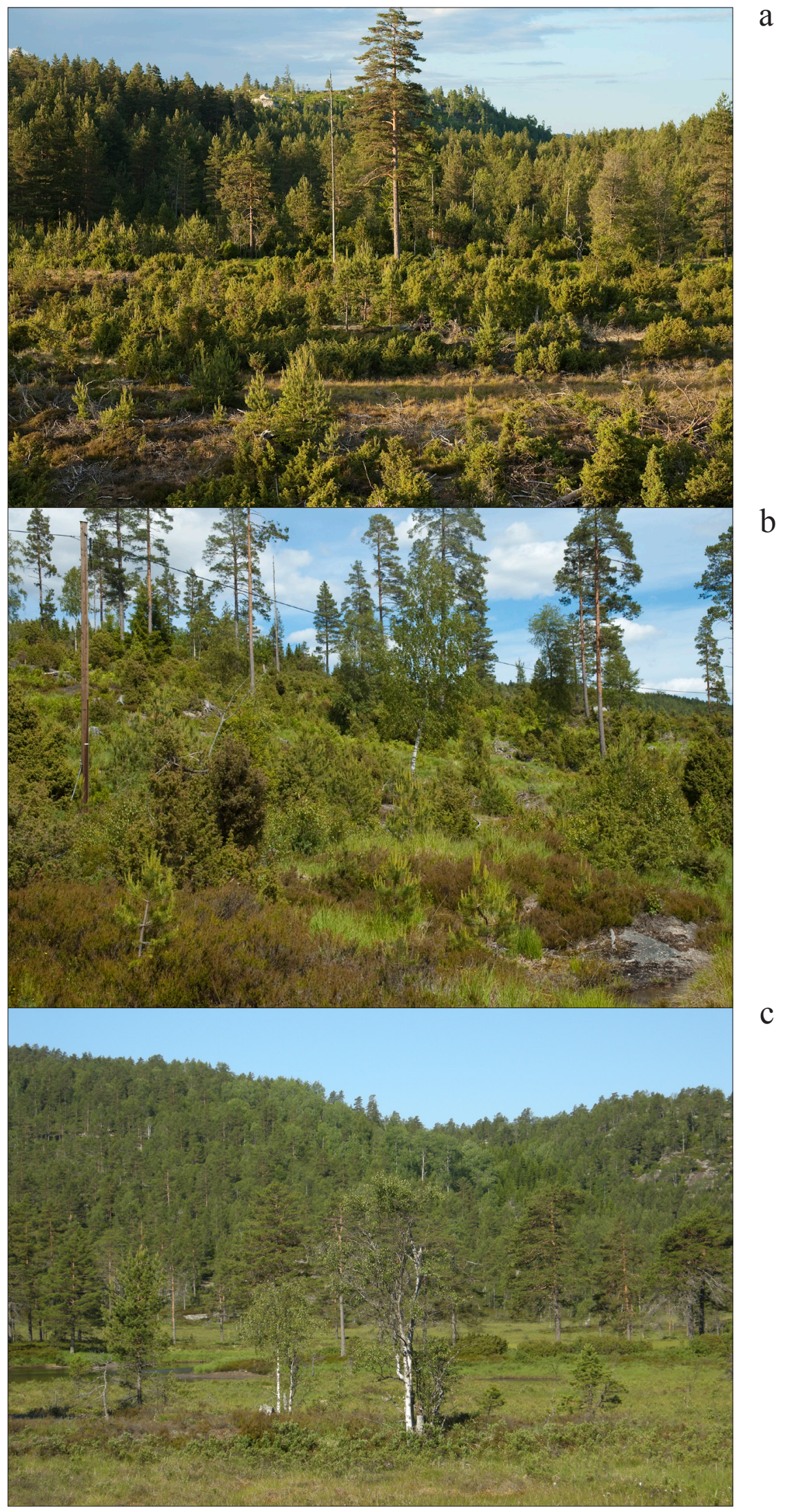

Figure 2. Examples of typical nest habitat for Red-backed Shrike within the study area. The species regularly occurred on clearcut areas in pine forest where the shrub layer was dominated by naturally growing junipers (a, b), but was sometimes also found in naturally open forest intermixed with mires (c). However, also in the latter case a certain cover of junipers appeared to be an important landscape component. 


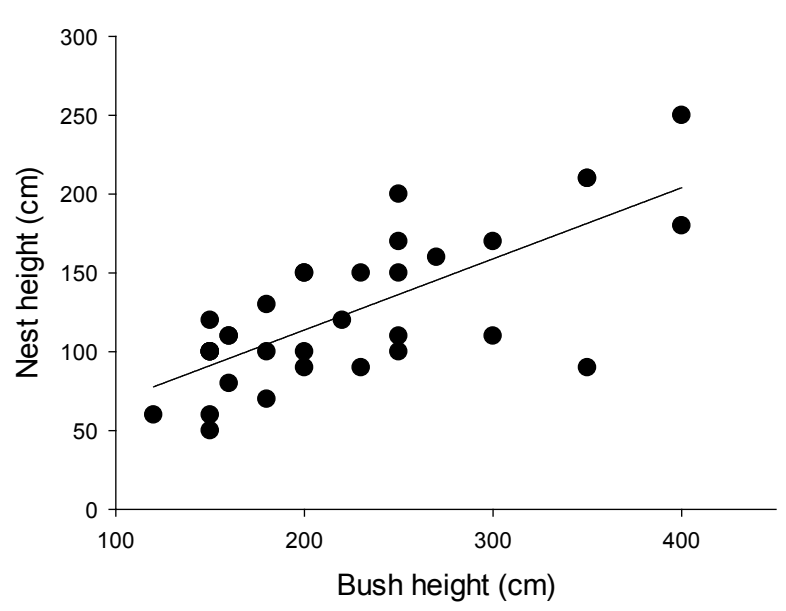

Figure 3. The correlation between nest height and height of the nest bush. The relationship is significant with a slope $<1$, indicating that nest height is not simply proportionally related to height of the nesting shrub.

remained unsuitable for Red-back Shrikes throughout the period of forest rejuvenation. Two nests were found in areas which did not show any recent signs of forestry activities and which could therefore be regarded as the species' natural habitat in this part of Norway (Figure 2c). In these cases the forest was naturally open and intermixed with larger areas of mire. However, also here junipers dominated the shrub layer.

Nest placement was recorded in 64 cases. Of these, $59(92.2 \%)$ were found in junipers, three $(4.6 \%)$ were found in spruce and one $(1.6 \%)$ in a young pine tree. The latter nest was located in a dense stand of young trees where the nest was invisible from the surroundings. In addition, one nest (1.6\%) was found just above the ground in a dense pile of dead twigs and branches resulting from forestry activities. Nest cover varied quite extensively, even for nests placed in junipers. Although many nests were completely concealed in dense shrub, others were easily visible from the sides with none or very few covering twigs and branches, or visible from one side of the bush but not the other.

Height of nests varied from ground level to about $250 \mathrm{~cm}$ above the ground $($ mean $=113 \pm 56 \mathrm{~cm}, \mathrm{n}=55)$. Estimated height of the tree or bush where nests were located varied from 120 to $400 \mathrm{~cm}$ (mean $=225 \pm 77$ $\mathrm{cm}, \mathrm{n}=34$ ). There was a positive correlation between nest height (dependent variable) and bush height (nest height $=$ bush height $\times 23.7+0.45 ; \mathrm{r}^{2}=0.52, \mathrm{~F}_{1,32}=$ $36.8, \mathrm{p}<0.001$; Figure 3$)$. However, the slope from this regression was significantly lower than $1(95 \% \mathrm{CI}=$ $0.30-0.60)$ which indicates that nests are placed lower than if nest height increased proportionally with bush height. Little information is available on the re-use of nests or nest sites, but in one case I found an active nest in a juniper which was placed on top of an old, previously undetected, nest.

Clutch size was distributed as follows: 1,3 and 7 eggs: $n=1 ; 4$ eggs: $n=11 ; 5$ eggs: $n=24 ; 6$ eggs: $n=18$ (mean clutch size $=5.1 \pm 1.0 ; \mathrm{n}=56)$. Estimated egglaying dates ranged from 15 May to 16 June (median $=3$ June, quartiles $=29$ May and 7 June, $n=41$ ), but note that a brood of fledged young 17 June 2004 is not included here as clutch size in this case was unknown. Assuming a chick age of 20 days and a clutch size of five, laying date in this case must have been no later than 10 May. Estimated hatching dates ranged from 28 May to 4 July (median $=20$ June, quartiles $=15$ and 25 June, $n=47$ ) and varied significantly between years (median hatching dates within years with at least three data points ranged from 9 June (1998) to 25 June (1996); Kruskal-Wallis test: $\left.\chi^{2}=20.4, \mathrm{df}=5, \mathrm{p}=0.001\right)$. There was no correlation between clutch size and hatching

a

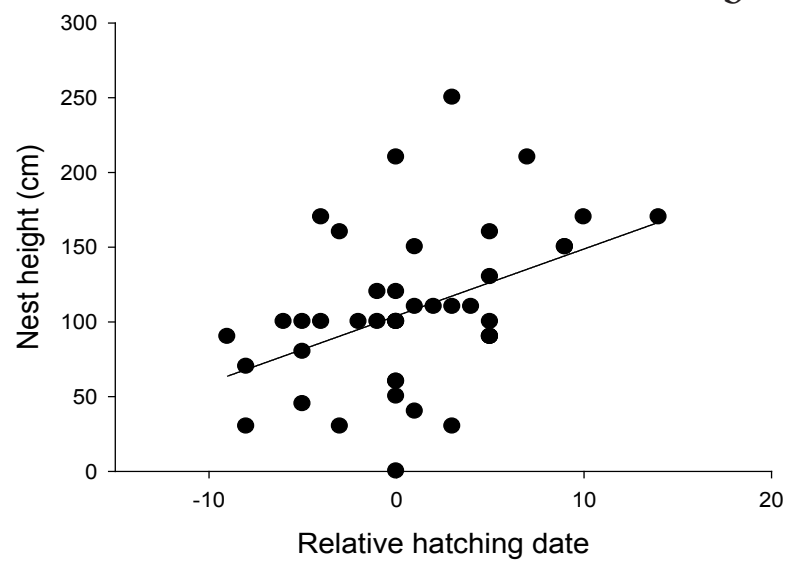

Figure 4. Nest height in relation to (a) hatching date and (b) relative hatching date. The latter is calculated as number of days from the median hatching date within each year (here 0). Negative values show the number of hatching dates prior to the median date, positive values are later than the median date. 
date $(\mathrm{r}=-0.17, \mathrm{p}=0.30, \mathrm{n}=41)$ or between clutch size and relative hatching date $(\mathrm{r}=-0.07, \mathrm{p}=0.77, \mathrm{n}=$ 41). Height of nest bushes increased significantly with both hatching date $(\mathrm{r}=0.63, \mathrm{p}=0.001, \mathrm{n}=25)$ and relative hatching date $(\mathrm{r}=0.48, \mathrm{p}=0.016, \mathrm{n}=25)$, as did nest height (hatching date: $\mathrm{r}=0.50, \mathrm{p}=0.001, \mathrm{n}=$ 42; relative hatching date: $\mathrm{r}=0.43, \mathrm{p}=0.005, \mathrm{n}=42$; Figure 4). However, there was no correlation between nest height and clutch size $(\mathrm{r}=-0.07, \mathrm{p}=0.61, \mathrm{n}=51)$.

\section{DISCUSSION}

In contrast to previous habitat descriptions from clearcuts further east where forests are dominated by Spruce, my study was done in Pine forests. Instead of young Spruce plantations, Juniper shrub here appears to be the key component of shrike habitat. This is probably also the case where Red-backed Shrikes breed in other parts of Aust-Agder and Vest-Agder counties, as the forest type in my study area is quite representative for the region. As a general guidance for forestry to create suitable habitat for Red-backed Shrikes I therefore recommend to retain Junipers in clear-cuts. As a way to producing good shrike habitat it would even be possible to selectively clear-cut forest where Junipers make up a large part of the shrub layer. In contrast to Spruce plantations which would need some time to mature such clear-cuts would instantly become useful shrike habitat.

Almost all nests in this study (92\%) were found in junipers, emphasizing the importance of this shrub as part of the shrike habitat in south Norway. Nests were also located lower than expected if nest height simply increased proportionally with bush height. Although junipers are reported as regular nest site for Redbacked Shrikes also in other studies $(<25 \%$; Cramp \& Perrins 1993, Olsson 1995b, Roos 2005), I am not aware of any other population where the proportion of nests placed in junipers, or in any other plant species, is so invariable. The reason for this low variability is most likely that plants described as important for nest placement elsewhere are not normally found in the study area, especially thorny bushes like bramble, blackthorn, hawthorn and dogrose. One could argue that the present study could not firmly support conclusions on habitat use and nest site selection in Red-backed Shrikes due to its non-random sampling procedures. More detailed and carefully designed studies of habitat selection are demanded in this Red-backed Shrike population to robustly analyse which factors best explain the species' presence, such as has been done in other boreal forests (Söderström 2009) and on farmland in central Europe (Vanhinsbergh \& Evans 2002, Brambilla et al. 2007, Titeux et al. 2007). Interestingly, habitat preferences vary over the breeding season in some areas, with density of blackthorn being important for pairs breeding early and juniper more important late in the summer (Söderström 2001). Future studies should therefore take into account variation in both time and space. It would then be possible to increase the precision of conservation recommendations by for example quantifying how large cover by junipers and other shrub makes an optimal shrike habitat, and if certain other characteristics like height of shrub are important.

In addition to junipers, spruce is the only other plant which commonly occurs in the study area, and which is known to be regularly used as nest site by Red-backed Shrikes. It would therefore be worthwhile to conduct a randomised study where the proportions of nests placed in juniper and spruce are compared with the relative availability of those plant species. The finding that nests were placed relatively low in the vegetation even in higher bushes suggests that reported nest heights typically ranging between 0.5 and $2 \mathrm{~m}$ (Cramp \& Perrins 1993) do not simply reflect the general bush height in typical Red-backed Shrike habitats. However, other characteristics of the nesting bush could explain this finding. For example, if higher junipers are rare in an area it would make the nests more conspicuous to potential nest predators if they were situated in the higher parts instead of low where vegetation cover and nest concealment is denser. Several studies have shown that predation is the main reason for nest failure in Redbacked Shrikes (Farkas et al. 1997, Söderström 2001, Roos \& Pärt 2004), and that predation risk affects nest placement (Farkas et al. 1997) and territory settlement (Roos \& Pärt 2004). It would therefore be interesting to know if characteristics of the juniper shrub which could affect predation risk, e.g. a bush's density (Müller et al. 2005) and whether it grows isolated or not, may be important for nest site selection in the species.

As previously shown in at least two other shrike species (Gawlik \& Bildstein 1990, Takagi \& Abe 1996), and a few other passerines (Rich 1980), I found that nest height increased with seasonal progress in Redbacked Shrikes. This corresponds with observations showing that, following predation, replacement nests in the species are placed higher above ground than first nests (Yosef 2008). Nevertheless, it is not clear if this pattern is caused by predation per se or some other underlying effect of seasonal progress. I was not able to detect replacement nests with certainty in this study and my results could therefore have been influenced by a large proportion of replacement nests late in the season. However, this is not likely because such nests should contain smaller clutches (normally 3-4 eggs; Roos 2005) and clutch size did not decrease with season in my study. In Bull-headed Shrikes Lanius bucephalus the positive correlation between nest height and seasonal progress could be attributed to a seasonal change in nest plant use (Takagi \& Abe 1996), but this was not the case in my study where nests were predominantly placed in junipers. Other 
researchers have suggested two additional explanations for this relationship (Woods \& Cade 1996), namely that nesting higher 1) reduces predation risk (predation hypothesis) and 2) improves air circulation and thus the microclimate for both eggs and incubating adults (microclimate hypothesis). Nevertheless, none of these hypotheses seem to be well tested so far.

The predation hypothesis probably stems from the observation in some bird species that nest failure rates decrease with nest height (Best \& Stauffer 1980). However, it is uncertain whether this relationship is affected by seasonal progress or not. Everything else being equal, I would assume nests to be more easily located by avian predators if they are placed higher off the ground and that lower nests are more easily detected by ground predators such as mammals or reptiles (see also Söderström et al. 1998). If so, the seasonal shift in nest height may be caused by a temporal change in the relative importance of avian and mammalian predators in determining nest failure. Studies have shown that predation risk in shrikes may decline over the season (Söderström 2001, Roos 2002). It would be interesting if future studies could incorporate nest height in such analyses. However, the relationships between nest height, breeding date and predation risk are further complicated by possible influence of spatial nest habitat components, particularly dominant plant species on the territory (Söderström 2001). The microclimate hypothesis could be tested by measuring and comparing nest temperature and nest humidity at different heights and with comparable nest concealment. Microclimate is likely to have a considerable effect on nest site selection in birds because it could affect both the thermal regulation of the eggs and adults. Yet, no one seems to have tested predictions of this idea so far by actually comparing microclimatic measurements from nest sites at different heights. While the need for good air circulation is probably high in hot and arid environments, overheating of nests should be a much smaller problem for Red-backed Shrikes breeding in temperate regions. In addition to previously suggested explanations, one could also envision the possibility that many birds in general, and shrikes in particular, prefer to nest in places where they have a fairly good overview of the surroundings. Such nest places may make incubating or brooding birds able to respond more quickly to approaching predators (Burhans \& Thompson 2001, Amat \& Masero 2004). In shrikes, higher nests should be better in this respect, especially later in the season when grass and broad-leaved shrub have grown taller and denser probably resulting in poor views from low nests. More studies would be necessary to test all these ideas and to see if there are other possible explanations to nest site selection patterns in both shrikes and other passerines.

I found a mean clutch size of five eggs which seems to be within the normal range for the species (e.g. Olsson 1995b, Tryjanowski 2002, Roos 2005). The variation in timing of breeding between years was probably caused by inter-annual variation in spring phenology (Olsson 1995b). Egg-laying phenology in this study was also similar to what is generally reported in Red-backed Shrikes from Sweden and Norway; i.e. with a peak in egg-laying in late May-mid-June (Haftorn 1971, Solheim 1994, Olsson 1995b, Roos 2005). The single case with an estimated laying date as early as 10 May must be exceptional in Norway, as birds normally arrive at their breeding sites around this time (Haftorn 1971, Olsson 1995b, Roos 2005, TL pers. obs.). However, it is possible that there is an ongoing shift towards earlier spring arrival dates in Norway, and consequently earlier laying dates, due to recent climate change. Such effects have been reported both from another Red-backed Shrike population (Hušek \& Adamík 2008) and in other passerines (e.g. Brown et al. 1999, Sanz 2003).

Acknowledgement: I am grateful to Ole Aa. Brattfjord and Kjell A. Johansson for providing nest data. I also thank Piotr Tryjanowski and Reuven Yosef for valuable comments on an earlier version of the manuscript. This paper is written in the memory of my good friend Kjell A. Johansson who encouraged me to study Red-backed Shrikes and who took actively part in much of the field work. In 2009 this study was funded by Norsk fuglevernsfond.

Sammendrag. Habitat og reirplassering hos tornskater som hekker på hogstflater i Sør-Norge. Informasjon om habitat, reirplassering og generell hekkebiologi til tornskaten Lanius collurio ble samlet inn fra i alt 71 reir i sørvestlige deler av Aust-Agder i perioden 1995-2009. Forekomster av arten var ganske forutsigbar på hogstflater der einerbusker utgjorde en vesentlig del av buskskiktet. Dette skiller seg fra tidligere studier av artens habitatvalg på hogstflater lenger øst, der forekomsten av unge grantrær har blitt framhevet som viktig. Reirene var nesten utelukkende plassert i einerbusker (92\%), noe som ytterligere styrker inntrykket av at denne busken er en svært viktig del av tornskatens hekkehabitat på Sørlandet. Reirene lå 0-250 cm over bakken (gjennomsnitt $=113 \mathrm{~cm}$ ). Reirets høyde økte med høyden til einerbusken som det lå i (gjennomsnittshøyde $=225 \mathrm{~cm}$, variasjon $120-400 \mathrm{~cm}$ ), men i mindre grad enn man skulle forvente dersom reirhøyde helt enkelt økte proporsjonalt med buskhøyde. Dette kan indikere at fuglene foretrekker å hekke relativt lavt i vegetasjonen selv når høyere alternativer er tilgjengelig. Kullstørrelse varierte fra ett til sju egg, men de fleste kullene besto av fem eller seks (gjennomsnitt $=5,1 \mathrm{egg}$ ). Estimerte eggleggingstidspunkt varierte fra ca. 10. mai til 16. juni (mediandato $=3$. juni). Hekketidspunkt varierte signifikant mellom år, men det var ingen korrelasjon mellom hekketidspunkt og kullstørrelse. Som det også har blitt påvist hos enkelte andre spurvefuglarter (inkludert varslere) økte både reirhøyden og høyden til reirbusker utover i sesongen, og mulige årsaker til dette blir diskutert. 


\section{REFERENCES}

Amat, J. \& Masero, J. A. 2004. Predation risk on incubating adults constrains the choice of thermally favourable nest sites in a plover. Animal Behaviour 67: 293-300.

Best, L. B. \& Stauffer, D. F. 1980. Factors affecting nesting success in riparian bird communities. Condor 82: 149158.

Brambilla, M., Rubolini, D. \& Guidali, F. 2007. Between land abandonment and agricultural intensification: habitat preferences of Red-backed Shrikes Lanius collurio in low-intensity farming conditions. Bird Study 54: 160167.

Brown, J. L., Li, S. H., Bhagabati, N. 1999 Long-term trend toward earlier breeding in an American bird: A response to global warming? Proc. Natl. Acad. Sci. USA 96: 55655569.

Burhans, D. E. \& Thompson, F. R. 2001. Relationship of songbird nest concealment to nest fate and flushing behavior of adults. Auk 118: 237-242.

Cramp, S. \& Perrins, C. M. 1993. Handbook of the birds of Europe the Middle East and North Africa. The birds of the western Palearctic. Vol. 7, flycatchers to shrikes. Oxford University Press, Oxford.

D’Alba, L., Spencer, K. A., Nager, R. G. \& Monaghan, P. 2011. State dependent effects of elevated hormone: Nest site quality, corticosterone levels and reproductive performance in the Common Eider. General and Comparative Endocrinology 172: 218-224.

del Hoyo, J., Elliott, A. \& Christie, D. 2008. Handbook of the birds of the world. Vol. 13, Penduline-tits to shrikes. Lynx Edicions, Barcelona.

Durango, S. 1956. Territory in the Red-backed Shrike Lanius collurio. Ibis 98: 476-484.

Farkas, R, Horváth, R. \& Pásztor, L. 1997. Nesting success of the Red-backed Shrike (Lanius collurio) in a cultivated area. Ornis Hungarica 7: 27-37.

Gawlik, D. E. \& Bildstein, K. L. 1990. Reproductive success and nesting habitat of Loggerhead Shrikes in northcentral South Carolina. Wilson bull. 102: 37-48.

Haftorn, S. 1971. Norges fugler. Universitetsforlaget, Oslo. (In Norwegian).

Hatchwell, B. J., Chamberlain, D. E. \& Perrins, C. E. 1996. The reproductive success of Blackbirds Turdus merula in relation to habitat structure and choice of nest site. Ibis 138: 256-262.

Hollander, F. A., Van Dyck, H., San Martin, G. \& Titeux, N. 2011. Maladaptive Habitat Selection of a Migratory Passerine Bird in a Human-Modified Landscape. PLoS ONE 6(9): e25703. doi:10.1371/journal.pone.0025703

Hušek, J. \& Adamík, P. 2008. Long-term trends in the timing of breeding and brood size in the Red-backed Shrike Lanius collurio in the Czech republic, 1964-2004. Journal of Ornithology 149: 97-103.

Karlsson, S. 2004. Season-dependent diet composition and habitat use of Red-backed Shrikes Lanius collurio in SW Finland. Ornis Fennica 81: 97-108.
Kålås, J.-A., Gjershaug, J. O., Husby, M., Lifjeld, J. T., Lislevand, T., Strann, K.-B., Strøm, H. 2010. Birds. In: The 2010 Norwegian Red List for Species. Artsdatabanken, Trondheim.

LeFranc, N. \& Worfolk, T. 1997. Shrikes. A guide to the shrikes of the world. Pica press, Sussex.

Martin, T. E. 1993. Nest predation and nest sites: new perspectives on old patterns. BioScience 43: 523-532.

Müller, M., Pasinelli, G., Schiegg, K. Spaar, R. \& Jenni, L. 2005. Ecological and social effects on reproduction and local recruitment in the Red-backed Shrike. Oecologia 143: 37-50.

Olsson, V. 1995a. The Red-backed Shrike Lanius collurio in south-eastern Sweden: Habitat and territory. Ornis Svecica 5: 31-41.

Olsson, V. 1995b. The Red-backed Shrike Lanius collurio in south-eastern Sweden: Breeding biology. Ornis Svecica 5: 101-110.

Ottvall, R., Green, M., Lindström, Å., Esseen, P.-A. \& Marklund, L. 2007. Landskapets betydelse för fåglarnas förekomst och populationsutveckling: en pilotstudie med monitoringdata från Svensk Fågeltaxering och NILS. Rapport, Ekologiska institutionen, Lunds universitet. (In Swedish).

Rich, T. 1980. Nest placement in Sage Thrashers, Sage Sparrows and Brewer's Sparrows. Wilson Bull. 92: 362368.

Roos, S. 2002. Functional response, seasonal decline and landscape differences in nest predation risk. Oecologia 133: 608-615.

Roos, S. 2005. Lanius collurio. Törnskata. Fact sheet from the Swedish Species Information Centre. (In Swedish).

Roos, S. \& Pärt, T. 2004. Nest predators affect spatial dynamics of breeding Red-backed Shrikes (Lanius collurio). Journal of Animal Ecology 73: 117-127.

Sanz, J. J. 2003. Large-scale effect of climate change on breeding parameters of Pied Flycatchers in western Europe. Ecography 26: 45-50.

Söderström, B. 2001. Seasonal change in Red-backed Shrike Lanius collurio territory quality - the role of nest predation. Ibis 143: 561-571.

Söderström, B. 2009. Effects of different levels of greenand dead-tree retention on hemi-boreal forest bird communities in Sweden. Forest Ecology and Management 257: 215-222.

Söderström, B. \& Karlsson, H. 2011. Increased reproductive performance of Red-backed Shrikes Lanius collurio in forest clear-cuts. Journal of Ornithology 152: 313-318.

Söderström, B., Pärt, T. \& Rydén, J. 1998. Different Nest Predator Faunas and Nest Predation Risk on Ground and Shrub Nests at Forest Ecotones: An Experiment and a Review. Oecologia 117: 108-118.

Solheim, R. 1992. Varslere. Pp. 121-131 in Hogstad, O. \& Semb-Johansson, A. (eds.): Norges dyr. J. W. Cappelens Forlag, Oslo. (In Norwegian).

Solheim, R. 1994. Tornskate Lanius collurio. P. 434 in Gjershaug, J. O., Thingstad, P. G., Eldøy, S. \& Byrkjeland, 
S. (eds.) 1994. Norsk Fugleatlas. Norsk Ornitologisk Forening, Klæbu. (In Norwegian).

Takagi, M. \& Abe, S. 1996. Seasonal change in nest site and nest success of Bull-headed Shrikes. Japanese Journal of Ornithology 45: 167-174.

Titeux, N., Dufrene, M., Radoux, J., Hirzel, A. H. \& Defourny, P. 2007. Fitness-related parameters improve presence-only distribution modelling for conservation practice: The case of the Red-backed Shrike. Biological Conservation 138: 207-203.

Tryjanowski, P., Kuzniak, S. \& Diehl, B. 2000. Does breeding performance of Red-backed Shrike Lanius collurio depend on nest site selection? Ornis Fennica 77: 137-141.

Vanhinsbergh, D. \& Evans, A. 2002. Habitat associations of the Red-backed Shrikes (Lanius collurio) in Carinthia, Austria. Journal für Ornithologie 143: 405-415.

Woods, C. P. \& Cade, T. J. 1996. Nesting Habits of the Loggerhead Shrike in Sagebrush. Condor 98: 75-81.

Yosef, R. 2008. Family Laniidae (Shrikes). Pp. 732-773 in: del Hoyo, J., Elliott, A. \& Christie, D. (eds.). Handbook of the birds of the world. Vol. 13, Pendulin-tits to Shrikes. Lynx Edicions, Barcelona.

Received 3 February 2012. Accepted 2 March 2012 